\title{
The progesterone content of rabbit uterine flushings
}

\author{
Ruth E. Fowler*, M. H. Johnson $\dagger$, D. E. Waltersł, and \\ Deborah D. Eager $\dagger$
}

\author{
Departments of $*$ Physiology and $\dagger$ Anatomy, Downing Street and \\ $\ddagger$ Department of Applied Biology, Pembroke Street, Cambridge, U.K.
}

\begin{abstract}
Summary. A detailed study has been made of the progesterone content of uterine flushings taken from rabbits of different endocrine states. A high content of progesterone was recovered from the uterine lumen of pregnant and pseudopregnant rabbits. The amount of progesterone recovered in the flushings was not simply dependent on the concentration in the plasma, because plasma progesterone concentrations rose before detection of progesterone in the flushings and remained high after uterine progesterone content had fallen. Progesterone did not appear in the uterine fluid unless uterine protein was present. This was particularly evident in rabbits treated with progesterone in which, despite abnormally high plasma concentrations, little progesterone was found in uterine fluid until the protein content increased. After treatment of rabbits with oestrogen at the time of ovulation, uterine progesterone was present in higher amounts concomitant with an elevation of protein content although the peak values of progesterone and protein were delayed by 2-3 days. Plasma progesterone concentrations of about $5 \mathrm{ng} / \mathrm{ml}$ were necessary before progesterone appeared in the uterine lumen.
\end{abstract}

\section{Introduction}

The mammalian uterus may exert considerable control over the development of the embryo at the time of implantation. In all species examined, asynchrony between uterus and embryo leads to reduced rates of embryonic survival (Adams, 1973), and in many species an obligatory or facultative delay in implantation is evident (Wimsatt, 1975; Aitken, 1977). It is accepted that the steroid hormones acting via uterine receptors mediate this control process (O'Grady \& Bell, 1977; Surani, 1977). Attention has concentrated on elucidating the linking mechanisms whereby the effects of the steroidreceptor interaction are transmitted to the embryo. The possibility also exists, however, of a direct effect of steroids on the embryo.

Preliminary reports have indicated that progesterone may be present in the fluid of the uterine lumen in very high concentrations during early pregnancy (Fowler, Johnson, Walters \& Pratt, 1976; Cowan, Manes \& Hagerman, 1976). It is possible therefore that a direct effect of steroids on the preimplantation embryo may be a component of the maternal control of embryonic development in some species. Steroids could operate either directly on embryo physiology or be used as a substrate for conversion to other steroids. The preimplantation pig embryo can effect conversion of progesterone to oestrogens (Gadsby, Burton, Heap \& Perry, 1976), and Dickmann, Dey \& Gupta (1975) claim to have detected histochemically some of the enzymes involved in steroid interconversion in a number of other species. It is therefore possible that any oestrogens produced by the embryo from maternal substrates could serve to convey information to oestrogen-binding sites in the corpus luteum (Perry, Heap, Burton \& Gadsby, 1976), the uterus, or within the embryo itself (Bullock \& Bhatt, 1973). We report here the results of a detailed study of steroid content of uterine flushings taken from rabbits in different endocrine states.

\section{Materials and Methods}

\section{Animals}

The New Zealand White rabbits were virgins (6-9 months old) and were divided into 5 groups. Those in Group 1 were mated twice to intact bucks; females in Group 2 were mated twice to vasectomized bucks; 100 i.u. HCG were injected subcutaneously to those in Group 3; does in Group 4 were 
given daily intramuscular injections of $3 \mathrm{mg}$ progesterone $/ \mathrm{kg}$ in arachis oil ; and does in Group 5 were given 100 i.u. HCG s.c. followed by two i.m. injections ( $100 \mu \mathrm{g}$ each) of oestradiol benzoate in arachis oil at 6 and $30 \mathrm{~h}$ later (Adams, 1973). For each group, Day 0 was taken to be $12 \mathrm{~h}$ after the injection of HCG or mating.

\section{Collection of samples}

Animals were anaesthetized with sodium pentobarbital (Nembutal: Abbott). Blood samples were withdrawn by cardiac puncture into heparinized syringes, and plasma samples were prepared by centrifugation at $4^{\circ} \mathrm{C}$ and stored at $-40^{\circ} \mathrm{C}$. Uterine horns were exposed, clamped at the vaginocervical junction, and $2 \mathrm{ml}$ cold sterile $0.9 \% \mathrm{NaCl}$ were injected into each horn at the uterotubal junction and then gently withdrawn. For Group 5,5 ml NaCl were used for each horn. Samples from each horn of a doe were pooled, centrifuged at $14,000 \mathrm{~g}$ for $30 \mathrm{~min}$ at $4^{\circ} \mathrm{C}$ and stored at $-40^{\circ} \mathrm{C}$. Corpora lutea in each ovary were counted.

\section{Protein estimations}

The total protein content of the uterine flushings was estimated by the technique of Lowry, Rosebrough, Farr \& Randall (1951): samples of flushings were applied to a G100 Sephadex column, and the eluted fractions were scanned for protein content. The third peak, which has previously been shown to be $90 \%$ or more uteroglobin (Johnson, 1972), was used to provide an estimate of uteroglobin content.

\section{Steroid estimations}

Steroids in uterine flushings and matching plasma samples were measured by radioimmunoassays (Abraham, Hopper, Tulchinsky, Swerdloff \& Odell, 1971; Abraham, 1974; Abraham, Manlimos, Solis, Garza \& Maroulis, 1975a; Abraham, Manlimos, Solis \& Wickman, 1975b). Progesterone was assayed in all samples and oestradiol-17 $\beta$, oestrone and androstenedione in samples from Groups 1 and 4.

Steroids in plasma and uterine fluids were extracted with ether after addition of the appropriate tritiated steroid containing approximately $2000 \mathrm{~d} / \mathrm{min}$ radioactivity as the internal standard for recovery estimates. Steroids in the ether extract were separated on celite microcolumns by the procedure described by Abraham, Buster, Lucas, Corrales \& Toller (1972), with a stationary phase of ethylene glycol. Three fractions were eluted, the first with $3.5 \mathrm{ml}$ iso-octane, the second with $3.5 \mathrm{ml}$ $10 \%$ ethyl acetate in iso-octane and the third with $3.5 \mathrm{ml} 40 \%$ ethyl acetate in iso-octane.

All the antisera used in the assays were kindly supplied by Dr G. E. Abraham. After incubating the purified steroid fraction with the specific antiserum overnight at $4^{\circ} \mathrm{C}$, the separation of bound from free steroid was effected by the addition of Dextran-coated charcoal. Triplicate measurements were used to establish the standard curve for each assay and duplicate samples were used to estimate the steroid concentration in uterine flushings and plasma samples. The concentration was calculated by interpolation from the standard curve which took the form of a non-linear asymptotic model which had been fitted to the standard curve by iterative methods (Walters, 1974). The mean of three blank samples was subtracted from the steroid levels in the sample before correction for recovery, the blanks being $<10 \mathrm{pg}$ in all assays.

The specificity and sensitivity of the antisera used in the present work and the accuracy of the method has been extensively tested by Abraham and his colleagues and was confirmed in the present study. In experiments designed to test the accuracy of the method by adding known quantities of progesterone to $1 \mathrm{ml}$ water samples, the value of measured progesterone did not differ by more than $10-15 \%$ from the expected value. Since only $30 \%$ of the total steroid present in each sample was used in the assay procedure and recovery estimates were between 60 and $80 \%$, the smallest amount of steroid that could be measured per sample was $0.04 \mathrm{ng}$ for progesterone, oestrone and androstenedione and $0.03 \mathrm{ng}$ for oestradiol-17 $\beta$. The precision of the assay was evaluated by duplicate measure- 
ments of the assay sample in the same or different assays. The average coefficient of variation ranged from $10 \cdot 2$ to $11 \cdot 8 \%$ within assays and from $11 \cdot 4$ to $14.7 \%$ between assays.

\section{Results}

Statistical examination of the temporal pattern of protein and progesterone content of uterine flushings suggested that there were no differences between the pregnant and pseudopregnant animals (Tables 1-3). The data for Groups 1, 2 and 3 were therefore combined for presentation in Text-fig. 1.

Table 1. Concentration (range in parentheses) of progesterone in plasma, and total quantities of protesterone and protein in the uterine flushings of pregnant rabbits (Group 1)

\begin{tabular}{|c|c|c|c|c|}
\hline $\begin{array}{c}\text { Day } \\
\text { of pregnancy }\end{array}$ & $\begin{array}{l}\text { No. of } \\
\text { animals }\end{array}$ & $\begin{array}{l}\text { Total protein } \\
\text { (mg/uterus) }\end{array}$ & $\begin{array}{c}\text { Total progesterone } \\
\text { (ng/uterus) }\end{array}$ & $\begin{array}{l}\text { Plasma progesterone conc. } \\
\qquad(\mathrm{ng} / \mathrm{ml})\end{array}$ \\
\hline $1 \frac{1}{2}$ & 3 & $0.08(0.01-0.32)$ & 0 & $0.27(0.24-0.30)$ \\
\hline $2 \frac{1}{2}$ & 3 & $0.51(0.10-0.92)$ & 0 & $1.61(1.55-1.65)$ \\
\hline $3 \frac{1}{2}$ & 3 & $1.48(0.54-2.35)$ & $1 \cdot 24(0.56-2.08)$ & $3.06(2.48-4.11)$ \\
\hline $4 \frac{1}{2}$ & 3 & $4.03(2.98-5 \cdot 25)$ & $5.98(4 \cdot 74-7 \cdot 23)$ & $4.90(4 \cdot 14-5 \cdot 89)$ \\
\hline $5 \frac{1}{2}$ & 3 & $2.90(2.45-3.68)$ & $20 \cdot 49(12 \cdot 24-31 \cdot 49)$ & $5.88(3.49-9.25)$ \\
\hline $6 \frac{1}{2}$ & 3 & $1 \cdot 14(1 \cdot 10-1 \cdot 20)$ & $21.96(14.66-33.47)$ & $4 \cdot 67(4 \cdot 21-5 \cdot 24)$ \\
\hline $7 \frac{1}{2}$ & 3 & $3 \cdot 82(1 \cdot 34-5 \cdot 13)$ & $11.50(8 \cdot 86-15 \cdot 26)$ & $7 \cdot 31(6 \cdot 21-8 \cdot 53)$ \\
\hline
\end{tabular}

Table 2. Levels (range in parentheses) of total protein and progesterone in uterine flushings, and plasma progesterone concentrations, of pseudopregnant rabbits (Group 2)

\begin{tabular}{|c|c|c|c|c|}
\hline $\begin{array}{c}\text { Day } \\
\text { of pregnancy }\end{array}$ & $\begin{array}{l}\text { No. of } \\
\text { animals }\end{array}$ & $\begin{array}{l}\text { Total protein } \\
\text { (mg/uterus) }\end{array}$ & $\begin{array}{l}\text { Total progesterone } \\
\text { (ng/uterus) }\end{array}$ & $\begin{array}{l}\text { Plasma progesterone conc. } \\
(\mathrm{ng} / \mathrm{ml})\end{array}$ \\
\hline$\frac{1}{2}$ & 3 & $0.27(0.20-0.38)$ & 0 & $0.20(0-3.26)$ \\
\hline $1 \frac{1}{2}$ & 3 & $0.12(0.01-0.24)$ & 0 & $0.73(0.08-0.14)$ \\
\hline $2 \frac{1}{2}$ & 3 & $0.66(0.21-0.96)$ & $0.51(0-1.52)$ & $1.71(1.40-2 \cdot 28)$ \\
\hline $3 \frac{1}{2}$ & 3 & $2.39(1.46-3.56)$ & $1.06(0.46-1.46)$ & $3.05(1.41-4.38)$ \\
\hline $4 \frac{1}{2}$ & 3 & $2 \cdot 41(1 \cdot 21-3 \cdot 56)$ & $0.78(0.29-1.55)$ & $3.05(1.60-4 \cdot 13)$ \\
\hline $5 \frac{1}{2}$ & 3 & $2.87(0.59-4.02)$ & $36 \cdot 52(27 \cdot 34-41 \cdot 71)$ & $7 \cdot 28(4 \cdot 87-6 \cdot 89)$ \\
\hline $6 \frac{1}{2}$ & 3 & $2.53(1.20-3.40)$ & $45.32(38.64-49.86)$ & $7 \cdot 54(5 \cdot 23-11 \cdot 54)$ \\
\hline $7 \frac{1}{2}$ & 3 & $2 \cdot 19(1.82-2.73)$ & $39 \cdot 28(29 \cdot 93-45 \cdot 32)$ & $8.06(5.84-11.40)$ \\
\hline $8 \frac{1}{2}$ & 3 & $0.77(0.51-1.14)$ & $9 \cdot 25(4 \cdot 87-12 \cdot 29)$ & $5 \cdot 22(4 \cdot 60-6 \cdot 37)$ \\
\hline $9 \frac{1}{2}$ & 3 & $0.64(0.40-1.00)$ & $7.80(1.33-15 \cdot 53)$ & $6 \cdot 36(4 \cdot 18-10 \cdot 16)$ \\
\hline $10 \frac{1}{2}$ & 3 & $0.58(0.47-0.71)$ & $1.60(0.40-3.82)$ & $6.03(3 \cdot 24-11 \cdot 32)$ \\
\hline $11 \frac{1}{2}$ & 3 & $0.64(0.50-0.78)$ & $1.61(0-3.93)$ & $5 \cdot 11(3 \cdot 33-7 \cdot 31)$ \\
\hline
\end{tabular}

Table 3. Levels (range in parentheses) of total protein and progesterone in uterine flushings, and of plasma progesterone concentration, of pseudopregnant rabbits (Group 3)

\begin{tabular}{|c|c|c|c|c|}
\hline $\begin{array}{c}\text { Day of } \\
\text { pseudo- } \\
\text { pregnancy }\end{array}$ & $\begin{array}{l}\text { No. of } \\
\text { animals }\end{array}$ & $\begin{array}{l}\text { Total protein } \\
\text { (mg/uterus) }\end{array}$ & $\begin{array}{c}\text { Total progesterone } \\
\text { (ng/uterus) }\end{array}$ & $\begin{array}{l}\text { Plasma progesterone conc. } \\
\text { (ng/ml) }\end{array}$ \\
\hline $1 \frac{1}{2}$ & $\begin{array}{l}3 \\
3\end{array}$ & $\begin{array}{l}0.40(0.08-1.00) \\
0.54(0.38-0.73)\end{array}$ & $\begin{array}{l}0.18(0-0.28) \\
0.12(0-0.35)\end{array}$ & $\begin{array}{l}0.25(0.13-0.33) \\
0.77(0.60-0.96)\end{array}$ \\
\hline $2 \frac{1}{2}$ & 3 & $1.05(0.76-1.38)$ & $0.06(0-0.18)$ & $0.97(0.73-2.00)$ \\
\hline $3 \frac{1}{2}$ & 3 & $3.38(2.54-5 \cdot 30)$ & $1.44(0.98-1.89)$ & $4.58(3.78-5 \cdot 38)$ \\
\hline $4 \frac{1}{2}$ & 3 & $3.91(3.40-4.40)$ & $11.48(5.48-20.45)$ & $5 \cdot 50(2 \cdot 10-10 \cdot 11)$ \\
\hline $5 \frac{1}{2}$ & 3 & $1.96(1.60-2.65)$ & $17 \cdot 44(14 \cdot 23-19 \cdot 82)$ & $4 \cdot 91(4 \cdot 19-5 \cdot 74)$ \\
\hline $6 \frac{1}{2}$ & 3 & $2 \cdot 74(2.35-3.32)$ & $31 \cdot 79(22 \cdot 88-46 \cdot 30)$ & $4.28(3.45-4.87)$ \\
\hline $7 \frac{1}{2}$ & 3 & $1.91(1.20-2 \cdot 76)$ & $19.55(0.77-30.80)$ & $7.71(5.55-9.97)$ \\
\hline $8 \frac{1}{2}$ & 3 & $1.15(0.78-1.38)$ & $24 \cdot 33(13 \cdot 90-43 \cdot 25)$ & $11 \cdot 71(8 \cdot 11-16 \cdot 71)$ \\
\hline $9 \frac{7}{2}$ & 3 & $1.24(0 \cdot 19-3 \cdot 14)$ & $13.99(1.47-37.94)$ & $4.85(4.01-5.69)$ \\
\hline $10 \frac{1}{2}$ & 3 & $0.50(0.20-0.90)$ & $3.47(0.65-8.54)$ & $3.98(3.23-5 \cdot 18)$ \\
\hline $11 \frac{1}{2}$ & 3 & $0.32(0.13-0.43)$ & $1.06(0.97-1.31)$ & $11.81(1.88-26.02)$ \\
\hline
\end{tabular}



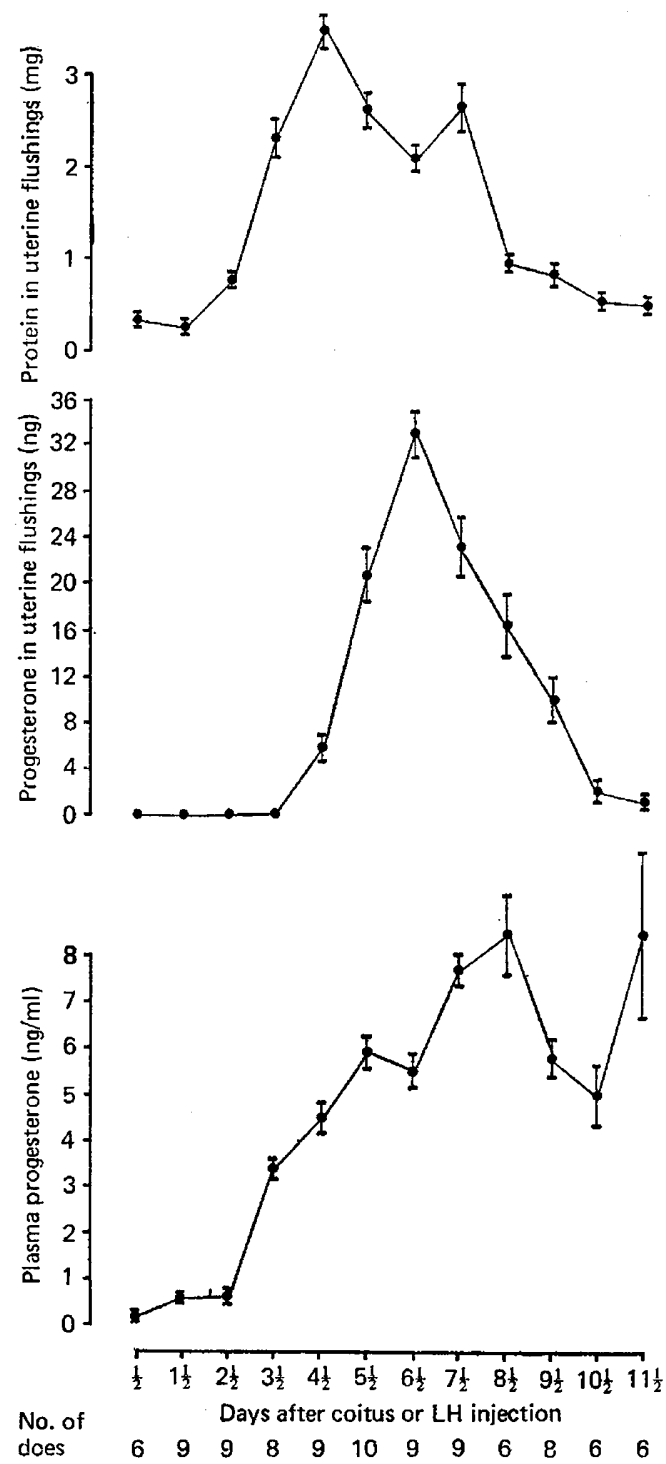

Text-fig. 1. The mean concentrations $( \pm 1$ S.E.) of progesterone and protein in uterine flushings and corresponding progesterone concentrations in the plasma of pregnant and pseudopregnant rabbits.

The plasma progesterone concentration rose sharply at 3 days to reach a fairly high level $(>5 \mathrm{ng} / \mathrm{ml})$ by 4-5 days which was then maintained throughout the experimental period. The content of protein in uterine flushings, and in particular of uteroglobin (Table 4), showed a substantial increase at Day 3 , whereas the increase in the content of uterine progesterone was not observed until $4 \frac{1}{2}$ days. No samples were collected at $7 \frac{1}{2}$ days in pregnant animals because flushing after this time damaged the implanting embryos and caused increased amounts of uterine protein. The steady decline in content of uterine progesteroneand protein in pseudopregnant animals from $8 \frac{1}{2}$ days onwards was not matched by a similar decline in the plasma concentration of progesterone.

In the Group 4 rabbits, plasma progesterone concentrations at all times greatly exceeded those encountered in normal pregnancy and pseudopregnancy, but the content of uterine progesterone remained low until uterine protein content was elevated (Table 5). The correlation coefficient between 
uterine progesterone content and plasma progesterone concentration was $\mathbf{0 . 3 1}$ (not significant) whereas the correlation between the uterine content of progesterone and that of protein was highly significant $(r=0.80, P<0.001)$. All correlation coefficients were calculated on logarithmically transformed variables.

Injection of high levels of oestradiol benzoate at 6 and $30 \mathrm{~h}$ after $\mathbf{L H}$ administration has been reported to change the temporal profile of uterine secretions (Beier, Kühnel \& Petri, 1971) and the synchronization requirements of the uterus (Beier, Mootz \& Kühnel, 1972; Adams, 1973). Compared with those of pseudopregnant and pregnant animals (Groups 1, 2 and 3) plasma progesterone

Table 4. Levels (range in parentheses) of total uteroglobin recovered in uterine flushings of pseudopregnant rabbits (Group 2)

\begin{tabular}{cccc}
\hline $\begin{array}{c}\text { Day of } \\
\text { pseudopregnancy }\end{array}$ & $\begin{array}{c}\text { No. of } \\
\text { animals }\end{array}$ & $\begin{array}{c}\text { Total uteroglobin } \\
\text { (mg/uterus) }\end{array}$ & $\begin{array}{c}\text { Uteroglobin } \\
\text { (as \% of total protein) }\end{array}$ \\
\hline$\frac{1}{2}$ & 2 & 0 & 0 \\
$1 \frac{1}{2}$ & 2 & 0 & 0 \\
$2 \frac{1}{2}$ & 2 & 0 & 0 \\
$3 \frac{1}{2}$ & 2 & $1 \cdot 15(0.99-1 \cdot 32)$ & $48 \cdot 12$ \\
$4 \frac{1}{2}$ & 2 & $1 \cdot 72(1.45-1.99)$ & 71.37 \\
$5 \frac{1}{2}$ & 2 & $1 \cdot 72(0.47-2.98)$ & 59.93 \\
$6 \frac{1}{2}$ & 2 & $1 \cdot 72(1.50-1.94)$ & 67.98 \\
$7 \frac{1}{2}$ & 2 & $0.95(0.90-1 \cdot 50)$ & 43.48 \\
$8 \frac{1}{2}$ & 2 & $0.42(0.32-0.52)$ & 54.55 \\
$9 \frac{1}{2}$ & 2 & $0.35(0.30-0.39)$ & 54.69 \\
$10 \frac{1}{2}$ & 2 & $0.15(0.14-0.15)$ & 25.86 \\
$11 \frac{1}{2}$ & 2 & $0.37(0.09-0.28)$ & 57.81 \\
\hline
\end{tabular}

Table 5. Levels (range in parentheses) of total protein and progesterone in uterine flushings, and of plasma progesterone concentration, of rabbits injected daily with $3 \mathrm{mg}$ progesterone $/ \mathrm{kg}$ (Group 4)

\begin{tabular}{ccccc}
\hline $\begin{array}{c}\text { Days after initial } \\
\text { progesterone injection }\end{array}$ & $\begin{array}{c}\text { No. of } \\
\text { animals }\end{array}$ & $\begin{array}{c}\text { Total protein } \\
\text { (mg/uterus) }\end{array}$ & $\begin{array}{c}\text { Total progesterone } \\
\text { (ng/uterus) }\end{array}$ & $\begin{array}{c}\text { Plasma progesterone conc. } \\
\text { (ng/ml) }\end{array}$ \\
\hline 1 & 3 & $0 \cdot 02(0-0 \cdot 03)$ & $0 \cdot 24(0-0 \cdot 34)$ & $15 \cdot 58(15 \cdot 38-15 \cdot 82)$ \\
2 & 3 & $0 \cdot 15(0 \cdot 02-0 \cdot 24)$ & $0 \cdot 89(0 \cdot 20-1 \cdot 51)$ & $28 \cdot 72(16 \cdot 97-48 \cdot 40)$ \\
3 & 3 & $0.94(0 \cdot 72-1 \cdot 07)$ & $3.92(2 \cdot 59-5 \cdot 87)$ & $35 \cdot 93(32 \cdot 48-39 \cdot 90)$ \\
4 & 3 & $1 \cdot 03(0 \cdot 68-1 \cdot 22)$ & $10 \cdot 26(5 \cdot 32-13 \cdot 93)$ & $30 \cdot 50(22 \cdot 29-29 \cdot 56)$ \\
5 & 3 & $1 \cdot 26(1 \cdot 10-1 \cdot 45)$ & $6.92(3 \cdot 35-11 \cdot 37)$ & $14 \cdot 25(10 \cdot 59-17 \cdot 16)$ \\
\hline
\end{tabular}

Table 6. Levels (range in parentheses) of total protein and progesterone in uterine flushings, and of plasma progesterone concentration, of rabbits injected with $\mathrm{HCG}$, and with $100 \mu \mathrm{g}$ oestrogen at $6 \mathrm{~h}$ and $30 \mathrm{~h}$ later

\begin{tabular}{cclcc}
\hline $\begin{array}{c}\text { Day of } \\
\text { pseudo- } \\
\text { pregnancy }\end{array}$ & $\begin{array}{c}\text { No. of } \\
\text { animals }\end{array}$ & $\begin{array}{c}\text { Total protein } \\
\text { (mg/uterus) }\end{array}$ & $\begin{array}{c}\text { Total progesterone } \\
\text { (ng/uterus) }\end{array}$ & $\begin{array}{c}\text { Plasma progesterone conc. } \\
\text { (ng/ml) }\end{array}$ \\
\hline $1 \frac{1}{2}$ & 1 & 0 & $6 \cdot 11$ & $2 \cdot 12$ \\
$2 \frac{1}{2}$ & 1 & $1 \cdot 25$ & $14 \cdot 84$ & $10 \cdot 30$ \\
$3 \frac{1}{2}$ & 1 & $1 \cdot 15$ & $1 \cdot 99$ & $9 \cdot 73$ \\
$4 \frac{1}{2}$ & 2 & $1 \cdot 84(0 \cdot 15-3 \cdot 53)$ & $4 \cdot 93(0 \cdot 30-9 \cdot 55)$ & $7 \cdot 15(2 \cdot 60-11 \cdot 70)$ \\
$5 \frac{1}{2}$ & 1 & $2 \cdot 54$ & $8 \cdot 48$ & $9 \cdot 27$ \\
$6 \frac{1}{2}$ & 2 & $6 \cdot 14(4 \cdot 50-7 \cdot 88)$ & $6 \cdot 62(2 \cdot 04-11 \cdot 20)$ & $13 \cdot 00(12 \cdot 42-13 \cdot 58)$ \\
$7 \frac{1}{2}$ & 2 & $7 \cdot 25(6.98-7 \cdot 53)$ & $20 \cdot 94(9 \cdot 54-32 \cdot 35)$ & $10 \cdot 36(9 \cdot 65-11 \cdot 08)$ \\
$8 \frac{1}{2}$ & 3 & $5 \cdot 82(5 \cdot 73-5 \cdot 95)$ & $61 \cdot 23(19 \cdot 91-83 \cdot 00)$ & $15 \cdot 29(4 \cdot 49-24 \cdot 71)$ \\
$9 \frac{1}{2}$ & 2 & $4 \cdot 48(3 \cdot 53-5 \cdot 43)$ & $73 \cdot 79(26 \cdot 13-121 \cdot 44)$ & $31 \cdot 72(17 \cdot 38-46 \cdot 07)$ \\
$10 \frac{1}{2}$ & 2 & $3 \cdot 80(1 \cdot 57-6 \cdot 02)$ & $85 \cdot 69(33 \cdot 11-138 \cdot 27)$ & $14 \cdot 55(14 \cdot 33-14 \cdot 75)$ \\
$11 \frac{1}{2}$ & 1 & $2 \cdot 0$ & $26 \cdot 42$ & $10 \cdot 09$ \\
$12 \frac{1}{2}$ & 2 & $0 \cdot 15(0 \cdot 14-0 \cdot 16)$ & $6 \cdot 24(4 \cdot 81-7 \cdot 67)$ & $8 \cdot 03(7 \cdot 09-8 \cdot 96)$ \\
\hline
\end{tabular}


concentrations in Group 5 rabbits rose earlier and to higher levels, uterine protein content rose at the same time but reached a later and higher peak, and the initial small rise in amounts of uterine progesterone was followed by a delayed rise to higher levels concomitant with that of the uterine protein in these flushings (Table 6).

The concentrations of some other steroids were measured in Groups 1 and 4. Plasma oestradiol$17 \beta$ values between $1 \frac{1}{2}$ and $7 \frac{1}{2}$ days of gestation were between 10 and $70 \mathrm{pg} / \mathrm{ml}$, and similar to published values (Challis, Davies \& Ryan, 1973), but no oestradiol-17ß or oestrone was found in the uterine flushings of either group. The levels of plasma androstenedione in rabbits treated with exogenous progesterone (Group 4: $0.52 \mathrm{ng} / \mathrm{ml}$ ) were elevated compared with those of pregnant rabbits (Group $1: 0.03 \mathrm{ng} / \mathrm{ml}$ ), but the levels of androstenedione in uterine flushings were negligible in both groups. The high levels of plasma androstenedione in Group 4 animals probably resulted from the peripheral conversion of progesterone to androstenedione. Because levels of oestradiol-17 $\beta$, oestrone or androstenedione were evidently negligible in uterine flushings, no further analyses of these steroids was undertaken in Groups 2, 3 or 5.

\section{Discussion}

These results demonstrate that large amounts of progesterone may be recovered from the uterine lumen of the progestational rabbit. Assuming a uterine fluid volume of $0.25 \mathrm{ml}$ per horn, the mean peak concentration of progesterone in uterine fluid of pregnant and pseudopregnant rabbits ranged between 44 and $90 \mathrm{ng} / \mathrm{ml}$. Since recovery was undoubtedly not $100 \%$ and since uterine fluid volume may be less than $0.25 \mathrm{ml}$, this calculated concentration of progesterone is likely to be a substantial underestimate. This figure is only slightly lower than our preliminary estimate $(138 \mathrm{ng} / \mathrm{ml})$ based on a small series of pseudopregnant rabbits in which the response to HCG was very variable(Fowler $e t$ al., 1976). Only trace amounts of the other steroids assayed were detected in uterine flushings despite appreciable plasma levels of one of these, androstenedione. The amount of progesterone recovered in the flushings did not follow the same pattern as plasma progesterone concentrations; for example, in pregnant and pseudopregnant animals (Groups 1-3) the plasma progesterone concentration rose before the progesterone content of the flushings, and remained high after the uterine content had fallen. The dissociation of uterine and plasma progesterone was particularly marked in the animals given daily progesterone injections (Group 4), in which plasma levels were much higher than those found in pseudopregnancy or pregnancy but uterine levels were lower. The passage of progesterone into the uterine lumen is not, therefore, simply dependent upon the level present in the plasma.

We have previously reported that a minimum of $80 \%$ of progesterone recovered in uterine flushings is bound to protein (Fowler et al., 1976) and that the amount of recovered progesterone and protein in uterine flushings were positively correlated. In the more extensive data presented here, it is clear that progesterone does not appear in the uterine fluid unless uterine protein is also present. Not only is this shown in the pregnant and pseudopregnant animals, but it is also particularly evident in progesterone-treated animals (Group 4) in which, despite the abnormally high plasma concentrations, little progesterone was found in uterine fluid until the content of uterine protein increased. In addition, in animals given oestrogen at the time of ovulation (Group 5), the peak values for the progesterone and protein content in the flushings were delayed by 2-3 days and both were considerably elevated compared with the values in untreated pseudopregnant rabbits (Group 2). It therefore seems reasonable to conclude that as long as progesterone levels in the plasma are adequate (around $5 \mathrm{ng} / \mathrm{ml}$ ), the appearance of the steroid in the uterine lumen is in large part regulated by the presence there of progesterone-binding proteins. The only protein from rabbit uterine flushings that has been shown to give quantitatively significant progesterone binding in vitro is uteroglobin (Beato \& Baier, 1975), and it seems probable that the uteroglobin also binds the progesterone in vivo.

It has been reported that low levels of uteroglobin and its mRNA are synthesized and secreted under the influence of oestrogens alone, higher levels are synthesized after progesterone injection alone, but maximal synthesis is achieved by a sequential oestrogen and progesterone stimulation (Beato \& Arneman, 1975; Rahman, Billiar \& Little, 1975; Beato \& Nieto, 1976; Beato, 1977). In our study, uterine protein levels were also lower with progesterone alone (Group 4), and despite the 
maintained presence of progesterone in pseudopregnant animals (Groups 2 and 3), uterine protein and uteroglobin levels fell after several days. In contrast, with oestrogen prestimulation (Group 5), the highest amounts of uterine protein were achieved. The oestrogen may act directly on the uterus to stimulate at the transcriptional or translational level, but the delay in occurrence of the peak of uterine protein after oestrogen stimulation might argue against this hypothesis. Alternatively, or in addition, oestrogen might act indirectly by stimulating the secretory activity of the the corpora lutea (Johnson \& Murray, 1974). The high plasma progesterone concentrations found in Group 5 would support such an action.

It is necessary to explain why, at plasma progesterone levels lower than $5 \mathrm{ng} / \mathrm{ml}$, uterine progesterone content is generally low even in the presence of increased protein. This situation may arise because the affinity of the reduced form of uteroglobin for progesterone has been reported to be only $3 \times 10^{-6}$ (Beato, 1976), which is lower than the affinities of progesterone for intracellular endometrial receptors or serum protein carriers (McGuire \& Bariso, 1972; Milgrom, Allouch, Alger \& Baulieu, 1973). Another explanation might be that some intermediary transport mechanism, which is dependent on higher progesterone levels than those stimulating uteroglobin secretion, must be activated before progesterone appears in the uterine lumen. It may also be that $20 \alpha$-dihydroprogesterone competes with progesterone for binding to protein in early pregnancy. The $20 \alpha$-dihydroprogesterone concentration is similar to that of progesterone in plasma from pregnant rabbits and even higher in pseudopregnant rabbits (Fuchs \& Beling, 1974). However, since Beato (1976) has shown that the relative affinity of $20 \alpha$-dihydroprogesterone for uteroglobin is low compared with progesterone this explanation appears unlikely. We are currently investigating these different possibilities.

The functional significance of progesterone in the uterine lumen is not established. Progesterone in high concentrations directly affects the stability of cell membranes (Weissmann, 1972) and may be immunosuppressive (see Carter, 1976). However, the progesterone concentrations estimated from data presented in this study (44-90 $\mathrm{ng} / \mathrm{ml}$ uterine fluid) are well below those known to exert an embryotoxic effect (Daniel \& Levy, 1964). The uteroglobin-progesterone complex may exert an endocrine effect on embryonic development or the interaction of the embryo with the uterus. It is possible that uteroglobin acts as a carrier of progesterone from maternal tissue to the embryo. Two reports have suggested that progesterone in the presence of binding proteins stimulates cell division and blastocyst expansion (El-Banna \& Daniel, 1972; Roblero \& Izquierdo, 1976), and uteroglobin has been shown to penetrate rabbit blastocysts (Kirchner, 1972). Pig blastocysts can utilize progesterone as a substrate for oestrogen synthesis (Gadsby et al., 1976) and 6-day rabbit blastocysts can synthesize cholesterol and pregnenolone from acetate and undertake certain steroid conversions (Huff \& Eik-Ness, 1966). These observations raise the possibility at least of a steroidal influence by the embryos of some species on uterine receptivity.

We wish to acknowledge gratefully the technical assistance of Mitzi Gooding and advice from Dr Azim Surani, and to thank particularly Dr C. E. Abraham for the provision of the antibodies used in this study. The work was supported by a grant to Professor C. R. Austin by the Ford Foundation.

\section{References}

Abraham, G.E. (1974) Radioimmunoassay of steroids in biological material. Acta endocr., Copenh., Suppl. $183,7-42$.

Abraham, G.E., Buster, J.E., Lucas, L.A., Corrales, P.C. \& Toller, R.C. (1972) Chromatographic separation of steroid hormones for use in radioimmunoassay. Analyt. Letters 5, 509-517.

AbrahaM, G.E., Hopper, K., Tulchinsky, D., SWERDLOFF, R.S. \& ODELL, W.D. (1971) Simultaneous measurement of plasma progesterone, 17-hydroxyprogesterone and oestradiol-17 $\beta$ by radioimmunoassay. Analyt. Letters 4, 325-335.

Abraham, G.E., Manlimos, F.S., Solis, M., Garza, R. \& MARoulis, G.B. (1975a) Combined radioimmunoassay of four steroids in one $\mathrm{ml}$ of plasma. I. Progestins. Clin. Biochem. 8, 369-373.

Abraham, G.E., Manlimos, F.S., Solis, M. \& Wickman, A.C. (1975b) Combined radioimmunoassay of four steroids in one $\mathrm{ml}$ of plasma. II. Androgens. Clin. Biochem. 8, 374-378. 
Adams, C.E. (1973) Asynchronous egg transfer in the rabbit. $J$. Reprod. Fert. 35, 613-614.

Artken, R.J. (1977) Embryonic diapause. In Development in Mammals, Vol. 1, pp. 307-360. Ed. M. H. Johnson. Elsevier North-Holland Biomedical Press, Amsterdam.

BeAto, M. (1976) Binding of steroids to uteroglobin. $J$. Steroid Biochem. 7, 327-334.

Beato, M. (1977) Physico-chemical characterization of uterglobin and its interaction with progesterone. In Development in Mammals, Vol. 2, pp. 173-198. Ed. M. H. Johnson. Elsevier North-Holland Biomedical Press, Amsterdam (in press).

Beato, M. \& ARneman, J. (1975) Hormone-dependent synthesis and secretion of uteroglobin in isolated rabbit uterus. FEBS Letters $58,126-129$.

BeAto, M. \& BAIER, R. (1975) Binding of progesterone to the proteins of the uterine luminal fluid. Identification of uteroglobin as the binding protein. Biochim. biophys. Acta 392, 346-356.

BeAto, M. \& NiETo, A. (1976) Translation of the mRNA for rabbit uteroglobin in cell-free systems. Eur. $J$. Biochem. 64, 15-25.

BeIER, H.M., Kühnel, W. \& Petri, G. (1971) Uterine secretion proteins as extrinsic factors in preimplantation development. Adv. Biosci. 6, 165-190.

BeIER, H.M., Mootz, U. \& KÜHNEL, W. (1972) Asynchrome Eitransplantationen wahrend der verzogerten Uterussekretion beim Kaninchen. In Proc. 7th Int. Congr. Anim. Reprod. \& A. I., Munich, Vol. 3, p. 1891.

Bullock, D.W. \& BHATT, B.M. (1973) Oestrogen binding to rabbit blastocysts and its possible role in implantation. J. Reprod. Fert. 35, 614-615.

CARTER, J. (1976) The effect of progesterone, oestradiol and $\mathrm{HCG}$ on cell-mediated immunity in pregnant mice. J. Reprod. Fert. 46, 211-216.

Challis, J.R.G., Davies, I.J. \& RYan, K.J. (1973) The concentrations of progesterone, estrone and estradiol- $17 \beta$ in the plasma of pregnant rabbits. Endocrinology 93, 971-976.

Cowan, B.D., Manes, C. \&. Hagerman, D.D. (1976) Progesterone concentration in rabbit uterine flushings before implantation. $J$. Reprod. Fert. 47, 359-361.

DANIEL, J.C., JR \& LeVY, J.D. (1964) The action of progesterone as a cleavage inhibitor of rabbit ova. J. Reprod. Fert. 7, 323-333.

Dickman, Z., DeY, S.K. \& Gupta, J.S. (1975) Steroidogenesis in rabbit preimplantation embryos. Proc. natn. Acad. Sci. U.S.A. 72, 298-300.

El-BanNA, A.A. \& DANIEL, J.C., JR (1972) Stimulation of rabbit blastocysts in vitro by progesterone and uterine proteins in combination. Fert. Steril. 23, 102 104.

Fowler, R.E., Johnson, M.H., Walters, D.E. \& PRATT, H.P.M. (1976) The progesterone and protein composition of rabbit uterine flushings. J. Reprod. Fert. 46, 427-430.

Fuchs, A.R. \& Beling, C. (1974) Evidence for eariy ovarian recognition of blastocysts in rabbits. Endocrinology 95, 1054-1058.

Gadsby, J.E., Burton, R.D., Heap, R.B. \& Perry, J.S. (1976) Steroid metabolism and synthesis in early embryonic tissue of pig, sheep and cow. $J$. Endocr. 71, 45-46P.

HuFf, R.L. \& EIK-Nes, K.B. (1966) Metabolism in vitro of acetate and certain steroids by six-dayold rabbit blastocysts. J. Reprod. Fert. 11, 57-63.

JoHNSON, M.H. (1972) The protein composition of secretions from pregnant and pseudopregnant rabbit uteri with and without a copper intrauterine device. Fert. Steril. 23, 123-130.

JoHnson, M.H. \& MURRAY, F.A. (1974) Effect of dosage of oestradiol-17 $\beta$ on the life-span of the rabbit corpus luteum. Experientia 30, 308-309.

KirChNER, C. (1972) Immune histologic studies on the synthesis of a uterine specific protein in the rabbit and its passage through the blastocyst coverings. Fert. Steril. 23, 131-136.

Lowry, O.H., Rosebrough, M.J., Farr, A.L. \& RANDALL, R.J. (1951) Protein measurement with the Folin phenol reagent. J. biol. Chem. 193, 265-275.

MCGuire, J.L. \& BARISO, C.D. (1972) Isolation and preliminary characterization of a progestogen specific binding macromolecule from the $273,000 \mathrm{~g}$ supernatant of rat and rabbit uteri. Endocrinology 90, 496-506.

Milgrom, K., Allouch, P., Alger, M. \& Baulieu, E.K. (1973) Progesterone-binding plasma protein of pregnant guinea pig. J. biol. Chem. 248, 1106-1114.

O'Grady, J.E. \& Bell, S.C. (1977) The role of the endometrium in blastocyst implantation. In Development in Mammals, Vol. 1, pp. 165-244. Ed. M. H. Johnson. Elsevier North-Holland Biomedical Press, Amsterdam.

Perry, J.S., Heap, R.B., Burton, R.D. \& Gadsby, J.E. (1976) Endocrinology of the early embryo and its role in the establishment of pregnancy. $J$. Reprod. Fert., Suppl. 25, 85-104.

Rahman, S.S.U., BilliaR, R.B. \& LiTtle, B. (1975) Induction of uteroglobin in rabbits by progestogens, estradiol-17 $\beta$ and ACTH. Biol. Reprod. 12, 305-314.

RoBlero, L. \& Izquierdo, L. (1976) Effect of progesterone on the cleavage rate of mouse embryos in vitro. J. Reprod. Fert. 46, 475-476.

SuRANI, M.A.H. (1977) Cellular and molecular approaches to blastocyst uterine interactions at implantation. In Development in Mammals, Vol. 1, pp. 245-305. Ed. M. H. Johnson. Elsevier NorthHolland Biomedical Press, Amsterdam.

WALTERS, D.E. (1974) The use of asymptotic models in multiple hormone assays. J. Roy. Stat. Soc. C 23, 43-50.

WeissmanN, G. (1972) The effect of steroids and drugs on lysosomes. In Lysosomes in Biology and Pathology, Vol. 1, pp. 276-295. Eds J. T. Dingle \& H. B. Fell. North-Holland Publishing Co., Amsterdam.

WimsatT, W.A. (1975) Some comparative aspects of implantation. Biol. Reprod. 12, 1-40. 